\title{
ORIGINAL
}

\section{Prevalence of injuries in triathletes from a French league}

\section{Olivier Galera ${ }^{\mathrm{a}, \mathrm{b}, *}$, Sophie Gleizes-Cervera ${ }^{\mathrm{a}}$, Fabien Pillard ${ }^{\mathrm{a}}$, Daniel Riviere ${ }^{\mathrm{a}}$}

\author{
a Department of Sports Medicine, Larrey University Hospital, Toulouse, France \\ ${ }^{b}$ Medical Committee of the Midi-Pyrenees Triathlon League
}

Received 10 February 2011; accepted 31 March 2011

Available online 28 October 2011

\section{KEYWORDS \\ Trauma disorders; \\ Frequency; \\ Triathletes; \\ Tendinitis; \\ Warm-up exercise; \\ Stretching}

\begin{abstract}
Objective: To assess the prevalence of trauma injuries in triathletes and look for contributing factors involved.

Method: An anonymous questionnaire about trauma history during the past season was sent by post to 788 triathletes from a French league.

Results: $52.4 \%$ of triathletes responding reported having been injured at least once during the past season, for $17 \%$ of them several times. $83.5 \%$ of injuries occurred during training, mostly in running (72.5\%). The tendinopathies (44.5\%), and muscle injuries (35\%), were the most frequently reported. The anatomical sites most frequently reported were the ankle $(20.6 \%)$, knee $(18.3 \%)$, thigh $(15 \%)$, lumbar region $(12.6 \%)$ and shoulder $(8,3 \%) .77 \%$ of injured triathletes were able to keep training, mainly in swimming $(71 \%)$ and cycling $(61.5 \%)$, while running was stopped in $85.5 \%$ of cases. Injured triathletes reported devote significantly less time to warmup than uninjured triathletes (respectively $13.7 \mathrm{~min}$ vs. $18 \mathrm{~min})(\mathrm{p}<0.01)$. Time devoted to stretching was also lower for injured vs. uninjured (respectively $8.3 \mathrm{~min}$ vs. $10.6 \mathrm{~min})(p<0.01)$. The same association was also found between time spent warming up and stretching and the prevalence of tendinopathies.

The prevalence of muscle injuries was significantly associated with number of training hours per week $(p<0.05)$ and weekly training distance swimming, cycling and running $(p<0.05)$. Conclusion: Injuries encountered in amateur triathletes are musculoskeletal injuries of «overuse», occurring mainly in training, especially running.

(c) 2011 Consell Català de l’Esport. Generalitat de Catalunya. Published by Elsevier España, S.L. All rights reserved.
\end{abstract}

\footnotetext{
* Corresponding author.

E-mail address: galera.o@chu-toulouse.fr (0. Galera).
} 


\section{PALABRAS CLAVE}

Trastornos

traumáticos;

Frecuencia;

Triatletas;

Tendinitis;

Ejercicios de

calentamiento;

Estiramiento

\section{Prevalencia de lesiones en triatletas de una liga francesa}

\begin{abstract}
Resumen
Objetivo: Evaluar la prevalencia de traumatismos en triatletas y buscar los factores contribuyentes implicados.

Método: Se envió por correo un cuestionario anónimo sobre los casos de traumatismos durante la temporada pasada a 788 triatletas de una liga francesa.

Resultados: El 52,4\% de los triatletas que respondieron notificaron que habían sufrido como mínimo una lesión durante la temporada pasada y el $17 \%$ varias lesiones. El $83,5 \%$ de las lesiones se produjeron durante el entrenamiento, sobre todo corriendo $(72,5 \%)$. Los casos notificados con más frecuencia fueron tendinopatías $(44,5 \%)$ y lesiones musculares $(35 \%)$. Las zonas anatómicas notificadas con más frecuencia fueron el tobillo $(20,6 \%)$, la rodilla $(18,3 \%)$, el muslo $(15 \%)$, la región lumbar $(12,6 \%$ y el hombro $(8,3 \%)$. El $77 \%$ de los triatletas lesionados pudieron seguir entrenando, sobre todo haciendo natación $(71 \%)$ y ciclismo $(61,5 \%)$, mientras que en el $85,5 \%$ de los casos tuvieron que dejar de correr. Los triatletas que habían sufrido lesiones notificaron que dedican un tiempo significativamente menor al calentamiento que los triatletas ilesos (respectivamente, $13,7 \mathrm{~min}$ frente a $18 \mathrm{~min})(\mathrm{p}<0,01)$. El tiempo dedicado a los estiramientos también era inferior en los lesionados en comparación con los ilesos (respectivamente, 8,3 min frente a 10,6 min) $(p<0,01)$. Se observó la misma asociación entre el tiempo empleado en el calentamiento y el estiramiento y la prevalencia de tendinopatías.

La prevalencia de lesiones musculares se asoció de manera significativa con el número de horas de entrenamiento semanales $(p<0,05)$ y con la distancia de entrenamiento semanal nadando, haciendo ciclismo y corriendo $(p<0,05)$.

Conclusión: Las lesiones observadas en triatletas amateurs son lesiones musculoesqueléticas por «abuso», producidas sobre todo durante el entrenamiento, principalmente al correr.

(C) 2011 Consell Català de l'Esport. Generalitat de Catalunya. Publicado por Elsevier España, S.L. Todos los derechos reservados.
\end{abstract}

\section{Introduction}

The rapidly increasing number of practitioners is accompanied by an increase in the frequency of consultations in medicine and sports trauma interesting triathletes, ${ }^{1}$ and this especially as this population appears to have substantial recourse to health professionals. ${ }^{2}$ Like any other sport, this implies for the practitioner to know the sport and its specific constraints in order to understand the specific pathologies. In the current state of knowledge, and as emphasized in a recent review of the literature, ${ }^{3}$ the lack of available data on the incidence, pattern of injuries and lack of evidence level studies published do not establishment of preventive medical recommendations in triathlon. ${ }^{1}$

The prevalence of injuries among triathletes found in the literature varies from 37 to $91 \% .4-10$ The differences in study populations, methodology, particularly about definition of injury or the method of data collection make it difficult to exploit these findings to develop recommendations for our league.

In June 2008, a preliminary study ${ }^{2}$ was conducted at the Revel triathlon (Midi-Pyrenees, France). The prevalence of injuries (tendinopathies and muscle injuries mainly) in the amateur triathletes seemed to justify the promotion of preventive health information in this population, particularly focusing on the need to observe a sufficient duration of warm-up. Nevertheless, this preliminary study was confined to a limited sample of the population of the league.

The aim of this retrospective study was to assess the prevalence, distribution of injuries and identify possible risk factors available for prevention. Relationships with age, sex, length of practice, level of practice and consequences on further training were also analyzed.

\section{Methods}

From senior and veteran triathletes of the league, 788 triathletes were selected.

Inclusion criteria were having a 2008/2009 license to practice recreational or competitive triathlon in MidiPyrenees league. Exclusion criteria were age under 18 or over 60 .

The triathletes were given clear information to ensure the anonymity of the data used and indicating the possibility that the results of the study may be the subject of communications in congresses or scientific publications.

A self-retrospective and anonymous questionnaire was sent to each of the 788 selected triathletes. The first four items related to age, sex, size and weight of respondents. The following eleven items related to the length and type of practice. The following eight items related to the trauma history of the past season $(2007 / 2008)$. Three items explored the time devoted to warm up in early training, stretching at the end of training, and daily hydration.

The number of triathletes required was calculated to measure a prevalence of $50 \%$ of an event with an accuracy of $3.5 \%$ in people $18-60$ years. The database was frozen for 2 months response time. Data were extracted and analyzed on Stata software (v6.0, Stata Corporation, Texas). For all analysis, the risk of first case was set at $5 \%$. 


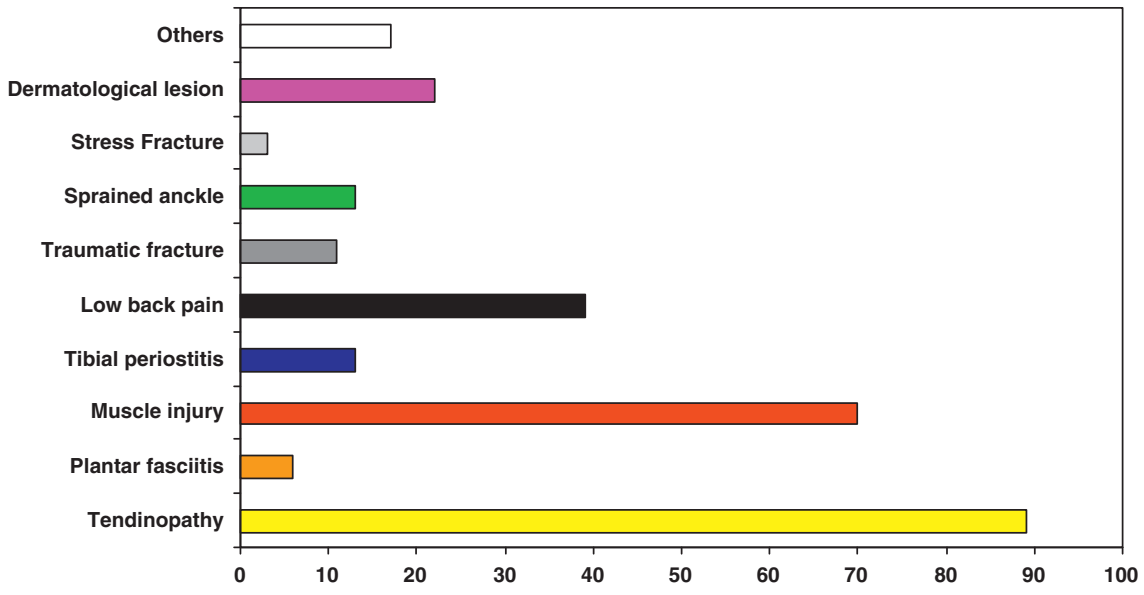

Figure 1 Distribution of types of injury.

\section{Results}

Three hundred and nine triathletes responded to the survey, representing a response rate of $49.4 \%$. The female population represented $17.9 \%$ of triathletes who responded to the survey, was significantly younger and reported a length practice significantly lower than the male population.

Practitioners of long distance (LD) were significantly older than the short distance (CD) (40 vs. 36 years respectively), with a length of practice also significantly higher (7.9 vs. 5.1 years). Although the elite group of triathletes was significantly younger (25.7 vs. 37.8 and 39.3 years for recreational and competitive groups respectively), their practice was significantly older (8.3 years respectively vs. 73 and 5.7 years). The average weekly volume of training was 8.9 hours for the three disciplines, representing an average of $4.6 \mathrm{~km}$ swim, $120.2 \mathrm{~km}$ bike and $26.8 \mathrm{~km}$ run. Men trained significantly more than women (respectively $9.2 \mathrm{vs} .7 .1 \mathrm{~h} /$ week) for an average of 4.3 events per year vs. 3.2 for women. Similarly, the average mileage in the three disciplines was higher among men, respectively, 4.8 vs. $3.8 \mathrm{~km}$ per week swimming, 131.9 vs. $65.2 \mathrm{~km}$ cycling, and 27.7 vs. $22 \mathrm{~km}$ running.

More than half $(52.4 \%)$ of triathletes $(52.9 \%$ men and $48.5 \%$ women) reported having been injured at least once during the past season (2007-2008), for $17 \%$ of them several times. There was no significant association between the prevalence of injuries and age of triathletes, length of practice, training volume, and number of annual competitions.

The injured triathletes reported devote significantly less time to warm-up (13.7 vs. $18 \mathrm{~min}$ respectively) and stretching ( 8.3 vs. $10.6 \mathrm{~min}$ respectively) than uninjured triathletes. At the contrary, there was no significant difference between the hydration of injured and uninjured triathletes (1.8 vs. $1.9 \mathrm{~L}$ of water per day respectively).

$83.5 \%$ of injuries occurred during training vs. only $16.5 \%$ during competition.

$3.9 \%$ of triathletes reported having been injured while swimming. The injuries occurred in swimming represented $7 \%$ of all injuries. The prevalence of injuries in swimming was significantly associated with training volume in swimming (8 vs. $4.6 \mathrm{~km}$ per week for injured and uninjured triathletes respectively) $(\mathrm{p}<0.001)$. At the contrary, there was no significant association between the prevalence of injuries in swimming and subject age or length of practice.

$12.4 \%$ of triathletes reported having been injured while cycling. Cycling injuries accounted for $22.5 \%$ of all injuries. In $73.3 \%$ of cases injuries were related to a fall. There was no significant association between the prevalence of injuries in cycling and the volume of training, age or length of practice.

$39.9 \%$ of triathletes reported having been injured while running. The injuries occurred during running accounted for $72.5 \%$ of all injuries.

The prevalence of injuries in runners seemed associated with the volume of training in running (28.6 vs. $25.6 \mathrm{~km}$ per week for injured and uninjured triathletes respectively) $(p=0.06)$. There was no significant association between the prevalence of injury in running and subject age or length of practice.

From the 389 triathletes responding, 200 injured triathletes reported a total of 293 injuries. The tendinopathies $(n=89)$ and muscle injuries $(n=70)$ were the most frequently reported (respectively 30.4 and $23.9 \%$ of all injuries), representing alone more than half (54.3\%) of all injuries (Fig. 1). Low back pain $(n=39)$ accounted for $13.3 \%$ of all injuries, ankle ligament sprains $(n=23) 7.9 \%$, skin lesions (abrasions after falling, sunburn) $(n=22) 7.5 \%$, tibial periostitis $(n=13)$ $4.4 \%$, traumatic bone fractures $(n=11) 3.8 \%$, and stress fracture $(n=3) 1 \%$, plantar fasciitis $(n=6) 2 \%$. Other types of injuries accounted for $5.8 \%$ of all injuries (Fig. 1).

More than two thirds of injuries were located in the lower limbs $(68.8 \%$ of injuries), to the lumbar region $(12.6 \%)$ and upper limb (8.3\%).

The ankle (20.6\%), knee (18.3\%) and thigh (15\%) alone accounted for over half of all injuries (53.8\%). The triceps surae injuries accounted for $7 \%$ of all injuries, the tibia (4.6\%) and foot (3.3\%). In the upper limb, the shoulder was the anatomic site most frequently affected $(8.3 \%$ of all injuries) $.10 .3 \%$ of injuries were located in other anatomical areas (Fig. 2).

Time devoted to warm-up was highly significantly associated with prevalence of tendinopathies $(p<0.0001)$. Injured triathletes reported spend $12.5 \mathrm{~min}$ to warm-up vs. $16.7 \mathrm{~min}$ for uninjured triathletes (Fig. 3). 


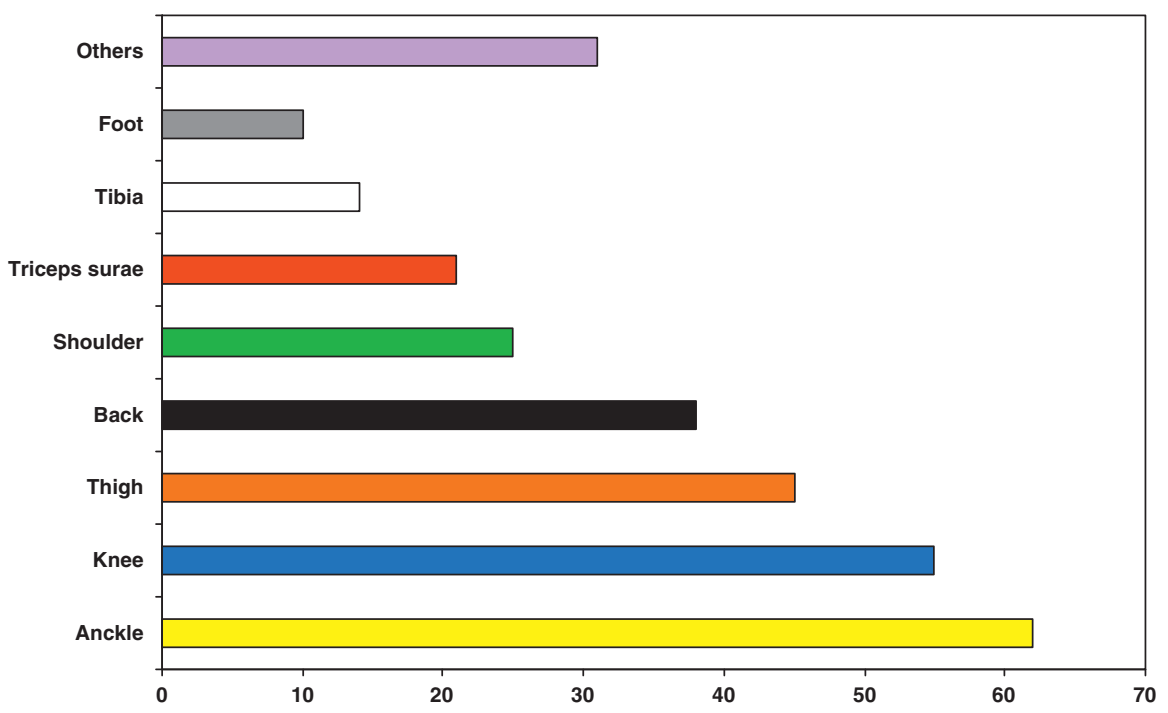

Figure 2 Distribution of anatomical sites of injury.

Time devoted to stretching at the end of training was also significantly associated with prevalence of tendinopathies $(\mathrm{p}<0.01)$. Injured triathletes reported spend $7.4 \mathrm{~min}$ stretching vs. $10 \mathrm{~min}$ for uninjured triathletes (Fig. 3).

There was no significant association between prevalence of tendinopathies and length of practice, total training, training volume in each discipline (swimming, cycling, running) or hydration issues.

Total training volume was significantly associated with the prevalence of muscle injuries $(p<0.01)$. The injured triathletes reported an average 10.1 hours training per week vs. 8.6 for non-injured triathletes.

The volume of training for each discipline (swimming, cycling and running), were significantly associated with prevalence of muscle injuries $(p<0.05)$. The injured triathletes reported significantly more training than non-injured: 5.6 vs. $4.4 \mathrm{~km}$ per week in swimming, $141 \mathrm{vs}$. $115.5 \mathrm{~km}$ per week in cycling, and 30.6 vs. $26 \mathrm{~km}$ per week running.

There was no significant association between the prevalence of muscle injuries and length of practice, time devoted to warm-up, stretching, and hydration.

91\% of the injured triathletes at least partially interrupted their training, but only $23 \%$ have to interrupt their

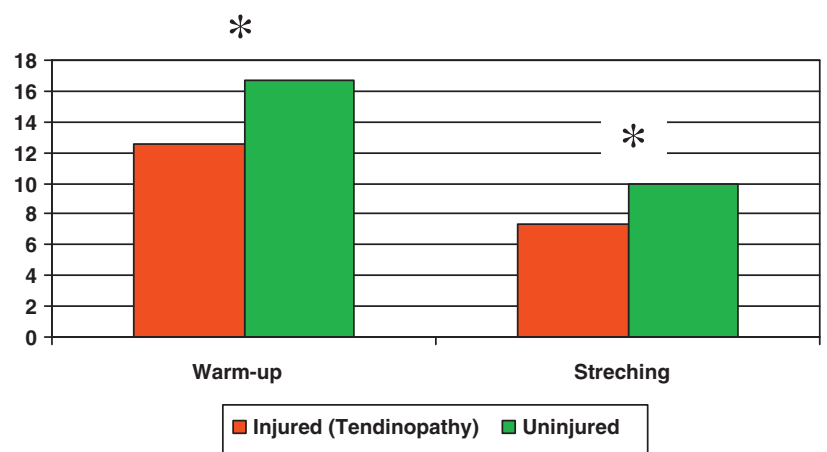

Figure 3 Time spent for warming up and stretching (in minutes) for injured subjects (tendinopathy) and uninjured (uninjured or injury different from tendinopathy) $\left({ }^{*} \mathrm{p}<0.01\right)$. training in all 3 disciplines. $77 \%$ were able to keep training in at least one discipline: $71 \%$ were able to continue training in swimming, $61.5 \%$ in cycling, but only $14.5 \%$ in running.

\section{Discussion}

In this study, retrospective data collection by selfadministered questionnaire (annex 1 ) may exhibit some bias. Some triathletes may report more injuries or increase their severity, whereas healthy triathletes may consider this study useless and have not returned the questionnaire.

In this study, the response rate $(49.4 \%)$ is higher than that of the main studies available in the literature. ${ }^{1,4-6,9}$ Only Vleck et al reported a higher response rate $(66 \%)$ but the number of triathletes $(n=116)$ was lower. The average distance of training was lower in this study compared to those described in other studies. ${ }^{5,21-25}$ On the over side, the competitive practice was similar to that described by other authors. ${ }^{1}$ As suggested by Korkia et al, ${ }^{9}$ the training loads reported by the amateur triathletes seem very important, especially among men ( 9.2 hours per week on average). These results and the nature of injury suggest probable errors in the planning of training.

The prevalence of trauma injuries in triathletes in this study (52.4\%) is higher than that found by Collins et $\mathrm{al}^{4}$ and Korkia et $\mathrm{al}^{9}$ but lower than that found by Egermann et al, ${ }^{1}$ Wilk et al, ${ }^{6}$ and 0 'Toole et al. ${ }^{5}$ The prevalence is also lower than suggested by our preliminary study $(62.8 \%)$ who had examined 43 triathletes. ${ }^{2}$

The distribution of injury suggested by our preliminary study ${ }^{2}$ is remarkably confirmed by the results of this study: $44.5 \%$ of triathletes reported having made a tendinopathy during the previous season (vs. $41.9 \%$ in the preliminary study) and $35 \%$ muscle injury (vs. 37\%). Tendinopathies and muscle injuries represented over half the injuries (54.3\%).

Overuse injuries were widely prevalent and accounted for 61.7 to $75 \%$, which is comparable to data from the literature (68-78\% for Burns et $\mathrm{al}^{12} 75 \%$ for Wilk and $\left.\mathrm{al}^{6}\right)$. 
More than two thirds of injuries were located in the lower limbs $(68.8 \%$ of injuries), which is consistent with data from literature. ${ }^{5,7-9,16}$ Most studies found lesions predominating in the knees ${ }^{10,21}$ and ankles ${ }^{4}$ and 50 to $75 \%$ of lesions associated with overload training in running. ${ }^{18-20}$

The prevalence of low back pain among triathletes warrants further specific studies. Several pathophysiological hypotheses have been proposed to explain the high prevalence of low back pain among triathletes: aerodynamic position on the bike, transition cycling-running, strengthening asymmetrical trunk flexors and cycling training volume. ${ }^{7,13,24}$

Shoulder injuries represented only $8.3 \%$ of injuries but we must notice the relative share devoted to swimming training compared to cycling and running, from these amateur triathletes. $4,5,7,8,17$

More than 8 out of 10 (83.5\%) injuries occur during training. Even if the time spent in competition has to be compared to training time, ${ }^{1,12}$ the most studies confirm that the most frequent injuries in triathlon training occur during running ${ }^{5,6,9,13}$ with a prevalence of injuries related to running ranging from 58 to $70 \%$ in the literature. ${ }^{4,8-10}$ In our study, the prevalence of injury in running is even more important $(72.5 \%)$. Running is so the most traumatic discipline, justifying the promotion of preventive strategies including the choice of specific and technical predilection on training volume. ${ }^{23}$

In our study, time devoted to warm-up and stretching was significantly associated with prevalence of tendinopathies, and also training volume was significantly associated with the prevalence of muscle injuries.

These results confirm that the sports medical examination of the triathlete must seek not only medical history but must also specify training habits, to assess risk factors trauma. ${ }^{12,16}$

\section{Conclusion}

The most frequently injuries encountered in amateur triathletes are musculoskeletal injuries of «overuse», occurring mainly in training, especially running. The prevalence of these lesions (tendinopathies and muscle injuries mainly) seem associated with errors in the planning of training (warm-up, stretching, volume...) which are all contributing or triggering factors accessible to a strategy of preventive medicine. These results confirm and complement those of the preliminary study conducted in 2008 , and should enable the medical committee of the league to promote prevention programs and to participate in improving the planning of training among Midi Pyrenees triathletes.

\section{Practical implications}

- These results confirm and complement those of the preliminary study conducted in 2008.

- They should enable the medical committee of the league to promote prevention programs.

- Triathlon coaches and triathletes could use the results of this study for improving the planning of training.

\section{Conflict of interests}

Authors declare that they don't have any conflict of interests.

\section{Acknowledgment}

Sanofi-Aventis France laboratories for financial support.

\section{Appendix A.}

\section{MEDICAL COMMISSION OF MIDI-PYRENEES TRIATHLON LEAGUE}

\section{EPIDEMIOLOGICAL STUDY}

Age: $\square \square$ years $\quad$ Gender: $\square$ Male $\square$ Female
Size: $\square \square \square \mathrm{cm}$

Years of triathlon: $\square \square$ years

Rather you practice: $\square$ Triathlon $\square$ Duathlon $\square$ Both $\square$ Short distance $\square$ Long distance $\square$ For the health -for leisure $\square$ Competition $\square$ Elite

Average hours of training per week: $\square$ hours

Average number of miles per week: km swimming $\square \square \square$ km cycling $\square \square$ km running

Average number of competitions per year: $\square$ triathlons $\square \square$ duathlons 
Have you been injured in the season 2007/2008? : $\quad \square$ YES $\square$ NO

If YES, have you been injured more than once? $\square$ YES ( $\square$ times) $\square$ NO

Have you been injured:

$\square$ In training $\quad \square$ In competition
$\square$ In swimming $\square$ In cycling $\square$ In running

What type of injury was it?

Tendon injuries (tendinitis, tendon rupture, plantar fasciitis ...)

Specify:

Muscle injury (contraction, elongation, strain, tear, ...)

Specify:

Bone lesion (fracture, periostitis, ...)

Specify:

Ligament injuries (ankle sprain, knee, ...)

Specify:

Low back pain ("back pain", "backache", ...)

Specify:

Skin lesions ("burns after falling," "Sunburn", ...)

Specify:

Other: Specify:

Where sat the injury?

$\square$ Back $\square$ Knee $\square$ Shoulder $\square$ Ankle $\square$ Other: Specify:

Do you have to interrupt your training because of this injury?

YES

In In the three disciplines

$\square$ in swimming $\square$ Cycling $\square$ Running

$\square$ NO

How long? : $\square \square$ days

Average time spent warming up at the start of training: $\square \square$ minutes

Average time spent on stretching at the end of training: $\square \square$ minutes

Average amount of water drunk per day:

Thank you for agreeing to complete this questionnaire will be analyzed guaranteeing the anonymity of the responder.

Dr Olivier GALERA

Federal Regional Medical

Regional League Triathlon

Thank you for returning the questionnaire in the pre-stamped envelope is essential before August 10, 2009

\section{References}

1. Egermann M, Brocai D, Lill CA, Schmitt H. Analysis of injuries in long-distance triathletes. Int J Sports Med. 2003;24:271-6.

2. Galera O, Gleizes-Cervera S, Pillard F, Rivière DI. Prevalence of injury among a sample of French amateur triathletes. Sciences and Sports. 2009;24:288-92.
3. Gosling CM, Gabbe BJ, Forbes AB. Triathlon related musculoskeletal injuries: the status of injury prevention knowledge. J Sci Med Sport. 2008;11:396-406.

4. Collins K, Wagner M, Peterson K, Storey M. Overuse injuries in triathletes. A study of the 1986 Seafair Triathlon. Am J Sports Med. 1989;17:675-80. 
5. O'Toole ML, Hiller WD, Smith RA, Sisk TD. Overuse injuries in ultraendurance triathletes. Am J Sports Med. 1989;17: 514-8.

6. Wilk BR, Fisher KL, Rangelli D. The incidence of musculoskeletal injuries in an amateur triathlete racing club. J Orthop Sports Phys Ther. 1995;22:108-12.

7. Manninen JS, Kallinen M. Low back pain and other overuse injuries in a group of Japanese triathletes. $\mathrm{Br} \mathrm{J}$ Sports Med. 1996;30:134-9.

8. Vleck VE, Garbutt G. Injury and training characteristics of male Elite, Development Squad, and Club triathletes. Int J Sports Med. 1998;19:38-42.

9. Korkia PK, Tunstall-Pedoe DS, Maffulli N. An epidemiological investigation of training and injury patterns in British triathletes. Br J Sports Med. 1994;28:191-6.

10. Clements K, Yates B, Curran M. The prevalence of chronic knee injury in triathletes. Br J Sports Med. 1999;33:214-6.

12. Burns J, Keenan AM, Redmond AC. Factors associated with triathlon-related overuse injuries. J Orthop Sports Phys Ther. 2003;33:177-84.

13. Migliorini S. An epidemiological study of overuse injuries in Italian national triathletes in the period 1987-1990. J Sports Traumatol Rel Res. 1991;13:197-206.
16. Cipriani DJ, Swartz JD, Hodgson CM. Triathlon and the multisport athlete. J Orthop Sports Phys Ther. 1998;27:42-50.

17. MCMaster WC. Swimming injuries. An overview. Sports Med. 1996;22:332-6.

18. Van Mechelen W. Running injuries. A review of the epidemiological literature. Sports Med. 1992;14:320-35.

19. James SL, Bates BT, Osternig LR. Injuries to runners. Am J Sports Med. 1978;6:40-50.

20. Hoeberigs $\mathrm{JH}$. Factors related to the incidence of running injuries. A review. Sports Med. 1992;13:408-22.

21. Massimino F. Common triathlon injuries: special considerations for multisport training. Annals of Sports Medicine. 1988;4:82-6.

22. Burns J, Keenan AM, Redmond A. Foot type and overuse injury in triathletes. J Am Podiatr Med Assoc. 2005;95:235-41.

23. Wilk BR, Fisher KL, Gutierrez W. Defective running shoes as a contributing factor in plantar fasciitis in a triathlete. J Orthop Sports Phys Ther. 2000;30:21-8.

24. Coste 0. Traumatology of triathlon. Available in: http: //www. msport.net/newSite/index.php?op=aff_article\&id_article=946.

25. Williams MM, Hawley JA, Black R, Freke M, Simms K. Injuries among competitive triathletes. New Zealand Journal of Sports Medicine. 1988;16:2-5. 